\title{
Role of Placental VDR Expression and Function in Common Late Pregnancy Disorders
}

\author{
Julia Knabl ${ }^{1,2}$, Aurelia Vattai ${ }^{1}$, Yao Ye ${ }^{1}$, Julia Jueckstock ${ }^{1}$, Stefan Hutter ${ }^{1}$, Franz Kainer ${ }^{2}$, \\ Sven Mahner ${ }^{1}$ and Udo Jeschke ${ }^{1, *}$ \\ 1 Department of Obstetrics and Gynecology, University Hospital, Ludwig-Maximilians Universität München, \\ 80337 Munich, Germany; Julia.knabl@gmx.de (J.K.); Aurelia.vattai@med.uni-muenchen.de (A.V.); \\ yao.ye@med.uni-muenchen.de (Y.Y.); julia.jueckstock@med.uni-muenchen.de (J.J.); \\ Stefan.hutter@med.uni-muenchen.de (S.H.); sven.mahner@med.uni-muenchen.de (S.M.) \\ 2 Department of Obstetrics and Gynecology, Klinik Hallerwiese, 90419 Nürnberg, Germany; \\ franz.kainer@diakonieneuendettelsau.de \\ * Correspondence: udo.jeschke@med.uni-muenchen.de; Tel.: +49-89-4400-54111; Fax: +49-89-4400-54916
}

Received: 26 September 2017; Accepted: 26 October 2017; Published: 6 November 2017

\begin{abstract}
Vitamin D, besides its classical role in bone metabolism, plays a distinct role in multiple pathways of the feto-maternal unit. Calcitriol is the major active ligand of the nuclear vitamin $\mathrm{D}$ receptor (VDR). The vitamin D receptor (VDR) is expressed in different uteroplacental parts and exerts a variety of functions in physiologic pregnancy. It regulates decidualisation and implantation, influences hormone secretion and placental immune modulations. This review highlights the role of the vitamin D receptor in physiologic and disturbed pregnancy, as preeclampsia, fetal growth restriction, gestational diabetes and preterm birth. We discuss the existing literature regarding common VDR polymorphisms in these pregnancy disorders.
\end{abstract}

Keywords: vitamin D; VDR; preterm birth; GDM; preeclampsia; fetal growth restriction

\section{Introduction}

The vitamin D endocrine system was formerly known as a key player in calcium and phosphate homoeostasis and in regulation of bone remodelling [1]. Hence, nowadays it is common knowledge, that the vitamin D endocrine system takes part in many non-classical pathways. Vitamin D influences maternal and fetal cell differentiation and cell growth, immune regulation, insulin secretion and anti-proliferative processes [2-5]. Therefore, this ligand is of special interest as it is involved in many diseases like autoimmune disorders, and type 2 diabetes mellitus (T2DM) [6,7].

The name vitamin is misleading, as in humans, only a small amount of vitamin D is obtained through dietary intake, while vitamin $\mathrm{D}$ is largely generated in the skin with exposure via photochemical conversion of 7-dehydrocholesterol to pre-vitamin D3, and the latter is sequentially metabolized in the liver and kidneys [8]. Extrarenal $1,25(\mathrm{OH})_{2} \mathrm{D}_{3}$ is metabolized by the colon, pancreas, immune system, endothelial cells and the placenta [9].

\subsection{Vitamin D Receptor (VDR) Signaling}

$1 \alpha, 25-(\mathrm{OH})_{2} \mathrm{D}$ (calcitriol) is the major active ligand of the Vitamin D receptor (VDR). VDR is part of the nuclear steroid hormone receptor family; and recruits another receptor of this group, for example, retinoid $X$ receptor $\alpha$ to form a heterodimer. This complex works as a transcriptional activator of numerous genes, via VDR response elements of the targeted genes [10]. However, vitamin D can also exert rapid non-genomic effects, probably via VDR located within the plasma membrane $[11,12]$.This rapid pathway works via specific enzymes as protein kinase $C$ and 
mitogen-activated protein kinase [13]. They regulate cell proliferation and cell differentiation, invasive processes and apoptosis.

\subsection{VDR Gene and Polymorphisms}

VDR is encoded by a capacious gene ( $>100 \mathrm{~kb})$, it lies on the chromosome 12q12-14 [14]. The VDR gene includes two promoter regions, eight coding exons (namely, 2-9), and six untranslated exons (1A-1F). In the VDR gene, single nucleotide polymorphisms (SNPs) occur quite frequently [15]. Every genetic variant is called a polymorphism if it appears in at least $1 \%$ of the population. Recently, multiple loci in VDR binding proteins and the modulating enzymes CYP2R1, CYP24A1, CYP27B1, and CYP27A1 genes have been linked to vitamin D levels [16,17].

Since the discovery of the VDR gene, common SNPs have been specified in the gene [15]. $V D R$ gene has four precise described di-allelic polymorphisms: BsmI (A > G, rs1544410) and ApaI (A > C, rs7975232) on the last intron, and FokI (C > T, rs10735810) and TaqI ( $\mathrm{T}>\mathrm{C}, \mathrm{rs731236})$ polymorphisms lie on the coding exons $[18,19]$. Several studies investigated these SNPs and associated them with a couple of diseases $[15,20,21]$ Therefore, $V D R$ allelic variants and different expressions of the receptor play a key role in a number of health concerns, as e.g., breast cancer or auto-immune diseases [22]. Hence, the role of $V D R$ and its allelic variants in pregnancy is not yet clarified [23]. A graphical view of VDR activation and its polymorphisms is presented in Figure 1.

The aim of this review was to summarize the existing knowledge about the role of VDR expression, function and polymorphisms in common pregnancy disorders.

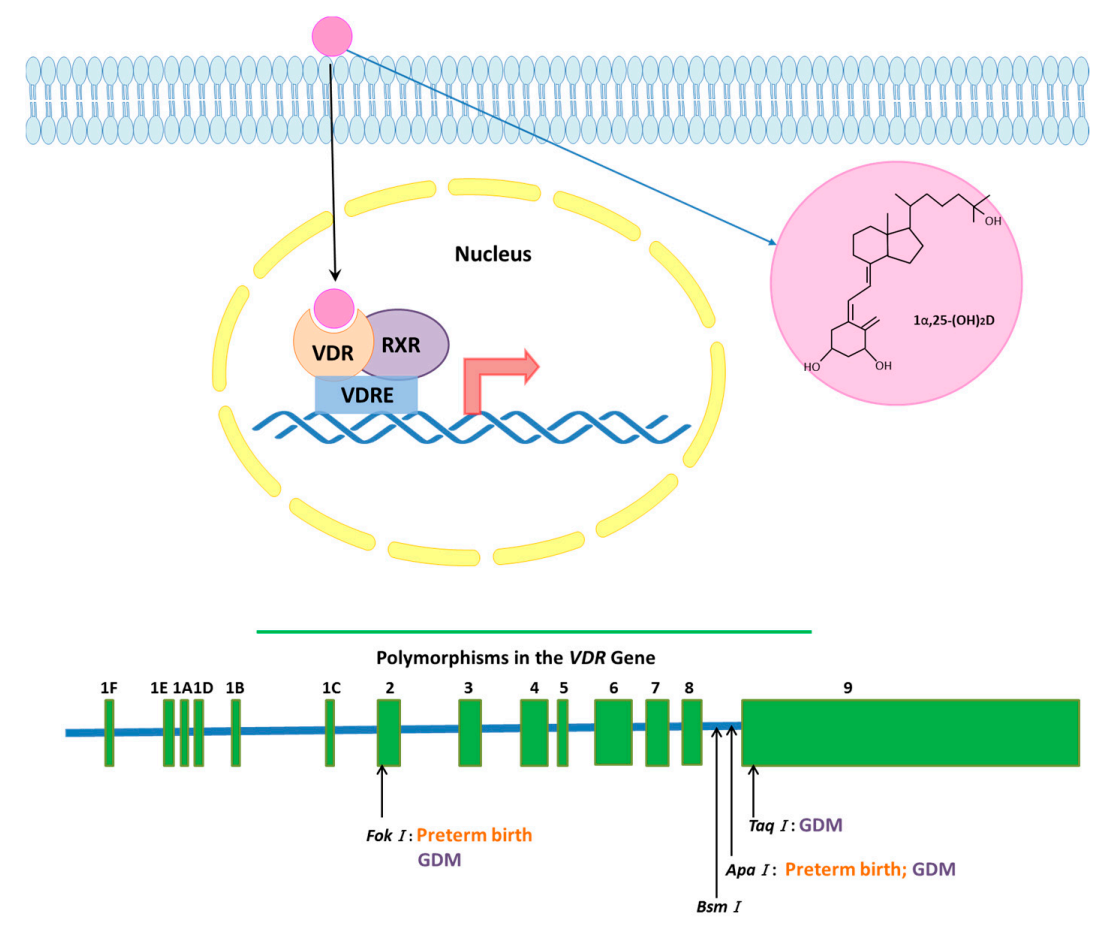

Figure 1. Vitamin D receptor expression and polymorphism: Vitamin D receptor (VDR) is a part of the nuclear steroid family and is also expressed in the plasma membrane. The major active ligand of VDR is $1 \alpha, 25-(\mathrm{OH})_{2} \mathrm{D}$ (calcitriol). In nucleus, VDR recruits retinoid $\mathrm{X}$ receptor (RXR) to form a heterodimer, which binds to vitamin D response element (VDRE) and modulates the transcription of numerous genes. VDR gene is located on the chromosome 12q12-14, which consists of eight protein exons (namely, 2-9) and six untranslated exons (1A-1F). VDR has four well-characterized di-allelic polymorphisms: BsmI and ApaI on the last intron, FokI and TaqI on the coding sequence. Among these polymorphisms ApaI, FokI and TaqI are linked to gestational diabetes mellitus (GDM), ApaI and FokI are linked to preterm birth. 


\section{VDR Expression in Physiologic Pregnancy}

Trophoblasts are a major source of $1,25[\mathrm{OH}]_{2} \mathrm{D}_{3}$ and during pregnancy it is elevated two folds [5]. It regulates decidualisation, implantation, lactogen expression. Furthermore, Vitamin D influences human chorionic gonadotropin (HCG), progesterone and estrogen secretion, calcium uptake into the placenta and placental immune modulations [24-27].

Placenta is also a major site for conversion of $25(\mathrm{OH}) \mathrm{D}_{3}$ to $1,25(\mathrm{OH})_{2} \mathrm{D}_{3}$ via CYP27B1 [28]. Placental calcitriol synthesis begins early in gestation, as placental expression of CYP27B1 mRNA is already high in the first trimester [28]. Increased levels of Calcitriol suppresses CYP27B1 transcription in trophoblasts $[29,30]$, in contrary CYP24A1 expression is upregulated. This effect works via ligand-bound VDR [29].

VDR expression was detected in villous trophoblast and decidua [31,32] and in smooth muscle cells of the placental vessels (VSMC) [2]. Nuclei of stromal cells in fetal villi and in the nuclei of fetal endothelial cells express also VDR [32]. VDR is known to regulate immune responses: Calcitriol stimulates the synthesis of cathelicidin (CAMP), an antimicrobial peptide, in trophoblasts, decidual cells and placental macrophages [30]. 1,25(OH ${ }_{2} \mathrm{D}_{3}$ decreases synthesis of cytokines including tumor necrosis factor, granulocyte-macrophage colony stimulating factor, and interleukin-6 in decidua [33], these results indicate that the vitamin D system may play an important role in controlling placental responses to infection. For example, placental synthesis of $1,25(\mathrm{OH})_{2} \mathrm{D}_{3}$ is induced by lipopolysaccharides (LPS), a Toll-like receptor 4 ligand (TLR4) by upregulation of CYP27B1 in mouse placenta [34].

Therefore, placental vitamin D system, including VDR, its ligands and the metabolizing enzymes like CYP27B1 plays a key role, possibly in combination with other factors like cytokines to maintain innate immunity and favours implantation [25,35].

\section{VDR and Preeclampsia}

Preeclampsia is defined by maternal hypertension, proteinuria and endothelial dysfunction, this syndrome affects up to $8 \%$ of pregnancies. It causes significant maternal and perinatal morbidity and mortality [36]. This accounts mostly for the severe, early onset form of preeclampsia, which has important pathophysiological overlaps with fetal growth restriction, and usually comes along with the latter. Placental insufficiency is a key characteristic of severe, early onset preeclampsia, and in addition of pregnancies with fetal growth restriction (FGR). Decreased trophoblast invasion, impaired placentation, disturbed remodeling of uterine arterioles [37], reduced cytotrophoblast proliferation and increased apoptosis [38] are specific observations in placental insufficiency.

Vitamin D deficiency is connected to placental insufficiencies like preeclampsia and fetal growth restriction. Several observational studies found significant associations between Vitamin D levels and an elevated risk of preeclampsia or gestational hypertension diseases [39-42], but overall results are conflicting: Three cohort studies and three case-control studies weren't able to identify a link between plasma $25(\mathrm{OH}) \mathrm{D}$ concentration and preeclampsia. Observations linked maternal Vitamin D and early onset and severe preeclampsia, but there was no association between maternal Vitamin D and late onset preeclampsia or overall preeclampsia risk [42,43]. However, the results are difficult to compare because of heterogeneity of populations, geographic location and lack of technical standardization in measurements. Other confounding factors, which influence vitamin D levels, are ethnicity, dietary habits, lifestyle and gestational age at sampling.

\subsection{VDR Expression Changes in Preeclampsia}

As to the specific placental metabolism, preeclampsia has recently been associated with decreased activation, increased catabolism, and impaired placental uptake of $25(\mathrm{OH}) \mathrm{D}_{3}$ [44]. In preeclampsia, which has significant pathophysiological overlaps with FGR, VDR expression is decreased [45-47]. Furthermore, placentas of preeclamptic women have reduced CYP27B1 enzyme 
activity in comparison to regular pregnancies [13]. One hypothesis connecting low vitamin D to the pathophysiology of preeclampsia is that vitamin D deficiency causes imbalances between Th1 to Th2 cytokines, while higher Th1 cytokine impairs embryo implantation [48]. Disturbed extravillous trophoblast (EVT) invasion of decidua and maternal spiral arteries is a key feature of preeclampsia and gestational hypertension. Recent data showed that calcitriol and calcidiol significantly increased EVT invasion in vitro [49]. Furthermore, in vitamin D deficiency is endothelial function of placental vessels disturbed and VDR expression on placental endothelium disturbed [23,50]. As genetic and epigenetic factors regulate protein expression, previous studies have reported that the placental Vitamin D concentration is influenced by epigenetic DNA methylation especially CYP24AI [51,52]. Therefore, hypermethylation of VDR gene may cause the downregulation of placental VDR in FGR-or preeclampsia.

\subsection{Role of VDR Polymorphisms in Preeclampsia}

There is a strong association between common VDR polymorphisms, as e.g., BsmI and FokI, and hypertension risk outside pregnancy [53-55]. In cell cultures, VDR-dependent signaling directly suppressed renin gene transcription [56]. FokI polymorphism of VDR influences plasma renin activity [57] and seems to be associated with a decreased risk of hypertension. Although there is also some evidence for a genetic contribution to hypertensive disorders of pregnancy [58-60], a recent case-control study found the three common VDR SNPs (FokI, ApaI and BsmI) equally distributed in gestation hypertension groups compared with healthy pregnancy cohort. In this study, neither these $V D R$ genetic polymorphisms nor $V D R$ haplotypes predisposed to preeclampsia or gestational hypertension [59].The authors concluded that other $V D R$ polymorphisms might affect the risk of getting preeclampsia or gestational hypertension, as the $V D R$ gene is very large (over 100,000 base pairs) $[56,61]$.

\section{VDR and Fetal Growth Restriction}

Fetal growth restriction (FGR) is a major health concern as it applies up to $5 \%$ of all pregnancies worldwide and is an important cause of perinatal mortality and morbidity [62]. Defining criteria include birth weight of less than the 10th centile for gestation and other signs of danger for the fetus, as e.g., low amniotic fluid s or asymmetric fetal growth [63]. A growth retarded fetus misses its genetically predetermined size for gestational age [64], this is the important difference too small for gestational age infants (SGA). FGR causes perinatal complications, for example an increased rate of stillbirth or prematurity. These children are at higher risk for several diseases, including cardiovascular disease and diabetes [65,66], asthma [67], or neurological sequelae as intellectual developmental delay [68], schizophrenia [69], depression [70].

FGR has multiple underlying reasons, as e.g., fetal chromosomal abnormalities, maternal nicotine abuse and malnutrition. However $\sim 70 \%$ of the cases are called idiopathic FGR as there is no evident reason to identify [71]. Characteristic signs of idiopathic FGR include is impaired function of uteroplacental vessels, including disturbed placental development and reduced flow from uterine vessels to the placenta [72]. The molecular pathophysiology is still not completely understood.

The possible mechanisms, which link vitamin D to fetal growth, are calcium metabolism, bone growth or altered placental function [73]. Vitamin D regulates via the VDR pathway human chorionic gonadotropin expression and secretion in human synctiotrophoblasts [2] and increases placental sex steroid production [24]. As it is explained in detail later in the manuscript, Vitamin D is also important in glucose/insulin homeostasis and for transplacental transport and fetal usage of glucose [74].

A systematic review linked maternal 25(OH)D and fetal growth by ultrasound [75] and several observational studies found associations between vitamin d levels and fetal growth [76-78]. Nevertheless, the results of the observational studies are conflicting: A multiethnic cohort study of pregnant women with vitamin D deficiency couldn't identify a link between maternal vitamin D levels and any of the neonatal anthropometric measures [79]. 
FGR placentae show significant different placental morphology such as reduced villous tree elaboration and diminished surface area [38]. In addition, trophoblast invasion and cytotrophoblast proliferation [38] is reduced, cytotrophoblast apoptosis [80] is increased. Additionally, the fusion of the villous trophoblast forming the multi-nucleated syncytiotrophoblast is impaired in placenta of FGR $[37,81]$.

\subsection{VDR Expression and Signaling in Fetal Growth Restriction}

VDR regulates cell proliferation and differentiation [82]. As mentioned above, VDR varies during pregnancy [31]. Placental VDR expression is decreased in human FGR and causes trophoblast dysfunction [83]. Therefore, decreased VDR expression may impair the actions and limits the beneficial effects of vitamin $\mathrm{D}$ in the regulation of feto-placental growth.

In in vitro studies, VDR plays critical roles in the maintenance of proliferation, migration, differentiation and apoptosis of the trophoblasts. This may be a link between the pathology of idiopathic FGR-affected pregnancies and the reduced VDR expression in such cases [23]. Placentae of FGR patients show impaired villous trophoblast fusion forming the syncytiotrophoblast [37,81,84]. VDR is a critical regulator of placental hormone secretion e.g., placental lactogen and $\beta$-hCG in BeWo cells. BeWo cells work well as in vitro model for the syncytiotrophoblasts $[27,85,86]$. VDR regulates BeWo cell differentiation via the influence on $\beta$-hCG expression. Furthermore, VDR inactivation affects syncytium formation in vitro and VDR inactivation promotes apoptosis, using TP53 mRNA as a marker of apoptosis [83]. Trophoblast syncytialisation is connected to decreased CYP27B1 in vitro [87]. VDR plays a role in protection against extrinsic apoptosis in placental insufficiency and maintains proper trophoblast function under adverse conditions like FGR [23]. As mentioned above, genetic and epigenetic regulations influence vitamin D effects on feto-placental development [88] and methylation changes in the VDR gene may reduce VDR expression in FGR [51,52].

\subsection{VDR Polymorphisms in Fetal Growth Restriction}

In addition, decreased expression of VDR in FGR may be due to SNPs of VDR, as polymorphisms influence expression and function of VDR [22,89]. VDR polymorphisms have been shown to modify offspring size; this was shown for the FokI genotype, but not for ApaI, BsmI, TaqI genotype. The latter have a high linkage disequilibrium in Caucasian population [90]. The ApaI polymorphism (rs7975232) is a non coding polymorphism of the VDR gene. Along with TaqI polymorphism (rs731236) this SNPs are associated with variation in mRNA stability [18]. As this influences the amount of protein, they might be able to change vitamin D levels and calcium homeostasis. However, the effect of a distinct maternal polymorphism on birthweight seems to differ across racial groups. In a prospective cohort study in North Carolina, a strong correlation between ApaI (rs7975232) and birthweight was identified in black mothers, but there was no association between any VDR SNP and birthweight for white mothers [91]. Common polymorphisms of $V D R$, which are associated with pregnancy complications, are listed in Table 1.

Table 1. Vitamin D Receptor (VDR) polymorphisms in pregnancy complications.

\begin{tabular}{cc}
\hline Polymorphism & Pregnancy Complication \\
\hline FokI & $\begin{array}{c}\text { Preterm birth } \\
\text { Gestational diabetes } \\
\text { Influence on offspring size }\end{array}$ \\
\hline ApaI & $\begin{array}{c}\text { Preterm birth } \\
\text { Gestational diabetes } \\
\text { Influence on Birth weight }\end{array}$ \\
\hline TaqI & Gestational diabetes \\
\hline
\end{tabular}

Table 1 shows the most common polymorphisms, which are associated with pregnancy complications in certain populations. 


\section{VDR and Diabetes in Pregnancy}

Gestational diabetes mellitus is a state of pronounced peripheral insulin resistance, which results in glucose intolerance in the second half of pregnancy. This concerns 3\% to $8 \%$ of all pregnancies depending on geographical location [92-94]. On one hand, GDM increases the risk of adverse pregnancy outcomes, as e.g., intrauterine fetal demise, fetal macrosomia, birth trauma and preeclampsia [95]. On the other hand, GDM influences health issues in later life of both mothers and their offspring, as overweight, type 2 diabetes mellitus (T2DM) and metabolic syndrome [96,97]. Vitamin D deficiency has been linked with insulin resistance in pregnancy [98] and with an increased risk of GDM [8]. Several studies have reported lower Vitamin D levels in women with GDM [8,99,100] or in the first half of pregnancy among women who later developed GDM. However, these results are controversial [101,102], other studies didn't see an association between Vitamin D levels and GDM [102,103]. The influence of individual, lifestyle and geographical factors on Vitamin D status is complex. Skin pigmentation, sun exposure, adiposity and diet are known to influence vitamin D. In addition, physical activity increases sun exposure and decreases body weight, as well as potentially the risk of GDM. In a large birth cohort study women with vitamin D deficiency had higher odds of GDM [104], but that this association diminished after adjustment for different confounders. Overall, systematic reviews and meta-analyses found a modest raise for the risk of GDM [73,105]. The outcome of these analyses are restricted by cohorts from different regions, the varying laboratory standards and timing of measurement of serum $25(\mathrm{OH}) \mathrm{D}$ level. The quantity of the effect of some influencing factors like ethnicity and adiposity are still unclear [106]. Until now, the exact mechanisms underlying the association of vitamin D and insulin resistance are not fully understood: In general, Vitamin D regulates about 3\% of the human genome, especially genes that influence glucose and lipid metabolism $[107,108]$. The following models link the pathogenesis of GDM with low levels of vitamin D [109-112]: Several studies demonstrated specific receptors for vitamin D in pancreatic $\beta$ cells [113] and a role for vitamin D in the secretion of insulin [114,115]. It also has been reported that vitamin D deficiency is associated with insulin resistance and T2DM [116,117].

Vitamin D regulates the balance between extra- and intracellular calcium. Calcium is an essential co-factor for insulin-mediated intracellular functions in insulin-depending tissues such as skeletal muscle and adipose tissue [118-120]. It is responsible for adequate insulin-mediated functions [121]. Changes in intracellular calcium contribute to peripheral insulin resistance as Calcium has to be in a very distinct range [121]. Insulin receptor phosphorylation is a calcium depending function as well [122]. Changes in Calcium concentration influences insulin signal transduction [120,123] and leads to decreased glucose transporter GLUT-4 activity $[123,124]$.The promoter region of the human insulin gene contains Vitamin D response element (VDRE) $[123,125]$ and so transcription of the human insulin gene is upregulated by $1,25(\mathrm{OH}) \mathrm{D}_{2}[126]$.

VDR influences glucose homeostasis via the insulin-like growth factor system. Vitamin D has an impact on the immune system [127] as VDRE is part of the promoter region of certain cytokines and has impact on cytokine generation and action [128-130] as for example NF-kB [130,131]. This is an important regulator of genes encoding pro-inflammatory cytokines implicated in insulin resistance [132] or calbindin [133,134], a cytosolic calcium-binding protein found in many tissues including pancreatic beta cells [134]. GDM is a proinflammatory state like preexisting diabetes [135]. Deficiency in immune modulations e.g., via itamin D deficiency causes an severe inflammatory response, which is an essential part of insulin resistance [136].

\subsection{VDR Expression in Gestational Diabetes Mellitus}

As to placental VDR expression changes in GDM, our recent work showed increased levels of VDR in extravillous trophoblasts and fetoplacental endothelium associated with maternal GDM [93]. Vitamin D protects endothelial tissue against renovascular dysfunction [137]. As Vitamin D induces NO production in endothelial cells, and endothelial dysfunction in GDM is accompanied by increased 
NO production, this link seems probable for GDM. Possibly, upregulation of VDR in the fetoplacental endothelium is a result of low vitamin D levels even in the fetus [93].

EVT displayed the strongest VDR upregulation of all placental parts [93]. EVT, which forms the fetomaternal interface, prevents allo-recognition and attacking of fetal cells by maternal natural killer cells, cytotoxic T cells, and macrophages [138]. As shown above vitamin D supports the immune system in both maternal and fetal compartments $[33,34,139]$ and it is a key regulator of placental inflammation [34]. GDM is an pro-infammatory state and VDR upregulation seems to compensate Vitamin D deficiency. A different study from Cho and co-workers [140] found no differences in VDR expression in GDM placenta, but they did not separate villous and extravillous trophoblasts. They found increased expression and production of CYP24A1 from patients with GDM compared with normal placental tissues and that serum vitamin $D$ level was correlated negatively with the expression of CYP24A1 in placenta. They concluded that increased placental expression and production of CYP24A1 may be responsible for the low level of vitamin D that is observed in GDM [140].

\subsection{VDR Polymorphisms and Gestational Diabetes Mellitus}

Available data suggest that GDM has genetic endowments in combination with environmental impacts [141]. Mothers with GDM often have a family history of diabetes and GDM recurs in at least $30 \%$ of women with a history of GDM [142,143], even in different populations [144,145]. VDR polymorphisms have been linked to a higher risk for type 1 diabetes mellitus (T1DM) [146,147] and type 2 diabetes mellitus (T2DM) [148]. As GDM and T2DM have a similar pathophysiology [149], polymorphisms in genes predisposing for diabetes mellitus Type 2 are closely related to GDM susceptibility [150]. Some VDR polymorphisms are strongly influencing the susceptibility to diabetes in general [148,151]: BsmIBB, BsmIBb, and TaqItt polymorphisms are linked to susceptibility of T1DM [152]. However, the connection between BsmI SNP and T2DM is weak. In a Chinese cohort, FokI polymorphism was significantly linked to T2DM risk, but not in Caucasians [153].

For the effect of $V D R$ polymorphisms in GDM, only a few studies are available. A link between VDR ApaI, TaqI, and FokI SNPs and risk for GDM was suggested in Iranian, Chinese and Saudi Arabian population $[144,145]$. But results with contrasting findings are available, as El-Beshbishy et al. couldn't link VDR BsmI and FokI polymorphism and GDM in a Saudi population [154]. In Chinese female genetic variants of Vitamin D binding protein and the heterodimers $\operatorname{RXR} \alpha$ and $\gamma$ had been identified as susceptibility markers for GDM [155]. See also Table 1 for common polymorphisms of VDR, which are associated with pregnancy complications.

To conclude, further studies are warranted with sufficient statistical power and with different ethnic background in order to confirm the potential of genetic biomarkers for prediction of GDM in different populations.

\section{VDR and Preterm Birth}

Preterm birth (PTB) is one of the leading problems in modern obstetrics. Deaths among premature infants account for $70 \%$ of all perinatal mortalities. The surviving ones are at risk for chronic lung disease, hearing, visual and cognitive impairments [156]. Hence, the pathophysiology of preterm birth is still unknown and heterogeneous, obviously intrauterine infection is a frequent and important mechanism causing early delivery [157]. Pro-inflammatory cytokines and genes probably trigger delivery at term [158]. Therefore, early excessive cytokine productions because of infection can lead to preterm labor.

Even though Vitamin D modulates immune responses and plays an important role in defending infections [127,159], findings from randomized [160] and epidemiologic studies of Vitamin D and preterm birth are controversial [76,161-164]. However, a very recent meta-analysis of 18 studies of either observational or interventional design, found sufficient evidence linking Vitamin D insufficiency with PTB. Serum $25(\mathrm{OH}) \mathrm{D}$ levels $<75 \mathrm{nmol} / 1$ was associated with $13 \%$ and $83 \%$ increased risk of PTB measured at $<35-37$ weeks and $<32-34$ weeks, respectively [165]. An inverse dose-response relation 
was noted for both PTB outcomes consistent with previous work linking maternal Vitamin D deficiency to bacterial vaginosis [166].

\subsection{VDR Signaling in Preterm Birth}

Experimental studies found associations between maternal Vitamin D status and placental antibacterial responses [30,33]. Toll-like receptors initiate the innate immune defense against microbial pathogens. Vitamin D reduces bacterial infections by inducing cathelicidin in decidua and cytotrophoblasts $[139,167]$. Low Vitamin D impairs toll-like receptor induction of the antimicrobial peptide cathelicidin from systemic macrophages [139]. Furthermore, calcitriol decreases expression of cytokines, such as granulocyte macrophage colony stimulating factor 2 (GMCSF-2), TNF- $\alpha$, IL-6. LPS increases inflammatory reactions in myometrial tissue [168] and myometrial smooth muscle (UtSM) cells [169]. LPS and IL-1 $\beta$ trigger preterm delivery in rodent models [170,171]. Vitamin D decreases both LPS- and IL-1 $\beta$-induced proteins in UtSM cells [172]. Therefore, Vitamin D attenuates the inflammation-induced expression of contractile-associated proteins in UtSM cells [34].

\subsection{Role of VDR Polymorphisms in Preterm Birth}

Information is sparse about association between preterm birth and VDR polymorphisms. BsmI, TaqI, ApaI, FokI SNPs were investigated by comparing maternal and neonatal genotype frequencies between the term and preterm cohorts.

In an Isreali population, the genotype frequencies of the VDR ApaI polymorphisms differed between term and preterm cohorts. Women carrying the VDR ApaI homozygote genotype had a higher risk for preterm births compared to the heterozygote group. This remained significant after adjustment for confounders. They couldn't find a link between VDR BsmI, TaqI or FokI variation frequencies between preterm and term births [173].

Manzon et al. investigated FokI, ApaI, TaqI and BsmI SNPs concerning the risk of spontaneous preterm birth in an Israeli population. In this population, maternal FokI and TaqI VDR allele frequencies were significantly different in the preterm birth group. However, only maternal FokI variant could be linked to an increased risk of preterm birth (odds ratio $\mathrm{OR}=3.317$ ). The ORs for the other variants such as TaqI, BsmI or ApaI were insignificant [19]. In addition, work from a polish group indicates that individual maternal SNPs of the VDR gene, namely the TaqI, BsmI and ApaI polymorphisms, had no effect on preterm birth. But they investigated some genotype combinations and e.g., some combinations reduced the risk for preterm birth significantly [174]. Polymorphisms of $V D R$, which are associated with pregnancy complications, are listed in Table 1.

\section{Existing Knowledge from VDR Knock-Out Models}

As elucidated above, common pregnancy complications are associated with impaired trophoblast function and impaired immune regulation on the feto-maternal interface. Even if we have multiple experimental and observational studies, a clear mechanistic link between VDR expression and placental function and therefore fetal outcome is still missing. Proper designed investigations with VDR knockout dams may add important knowledge in this area:

VDR knockout $\left(\mathrm{Vdr}^{-/-}\right)$mice had lower fetal weights in comparison to heterozygous $\left(\mathrm{Vdr}^{+/-}\right)$ animals [175]. As mentioned above, investigations in knockout VDR and Cyp27b1 knockout mice showed that Vitamin D controls placental inflammation [34]. Wilson et al. found no differences in morphology of $V d r^{-/-}$fetus or placenta, when the $V d r^{+/-}$mother was fed with sufficient vitamin D and calcium [176]. Dams with a vitamin D deficient diet had reduced placental size [177]. The authors concluded that it might be the decidua, which mediates the impact of low maternal vitamin $\mathrm{D}$ on the placenta, rather than direct VDR signaling in the placenta [176]. Interestingly, the authors detected that especially some genes which are involved in oxidative stress and fetal growth are different between $V d r^{-/-}$and $V d r^{+/+}$placentae [176]. This might be a link to development of pregnancy complications like preeclampsia [178]. 


\section{Conclusions}

To conclude, the evidence out of experimental studies is convincing, Vitamin D together with the placental nuclear receptor VDR has important impact on the fetomaternal unit in multiple pathways. VDR influences trophoblast differentiation and function, regulates immune reactions and inflammation. However, existing clinical studies give conflicting results about the impact of vitamin $D$ in pregnancy disorders. Vitamin D status is influenced by dietary habits, skin pigmentation, sun exposure, adiposity and missing standardization of measurements. These factors hinder proper design and reproducibility of clinical studies. Furthermore, the relationship between a polymorphism and phenotype cannot be clarified upon in studies where individual SNPs are analyzed in isolation and interpretation of association studies involving the VDR gene are difficult because most of the SNPs are non-coding. The aim of further designed studies should be to investigate the functional haplotype structure of $V D R$ polymorphisms in different populations.

Taken together the knowledge about vitamin D and placental VDR, we assume that disturbances in VDR expression and function, which result in pregnancy complications, may refer mainly to the maternal part of the placenta. Information about the consequences of defective VDR signaling in the fetus or the fetal part of the placenta are still missing, especially regarding the long time outcome of the offspring. Further investigations, which distinguish properly between fetal and maternal parts of the placenta and provide data about fetal programming, are warranted for the prevention of vitamin $D$ related diseases in the offspring.

Acknowledgments: We thank the Medical Faculty of the Ludwig-Maximilians-Universität München (LMU Munich) for financial support.

Author Contributions: Julia Knabl and Aurelia Vattai wrote the review, Yao Ye prepared the figure, Julia Jueckstock, Stefan Hutter and Franz Kainer revised the manuscript, Sven Mahner supervised the research study and Udo Jeschke gave final approval.

Conflicts of Interest: The authors declare no conflict of interest.

$\begin{array}{ll}\text { Abbreviations } \\ \text { CAMP } & \text { Cathelicidin } \\ \text { EVT } & \text { Extra villous trophoblast } \\ \text { FGR } & \text { Fetal growth restriction } \\ \text { GDM } & \text { Gestational diabetes mellitus } \\ \text { LPS } & \text { Lipopolysaccharide } \\ \text { PTB } & \text { Preterm birth } \\ \text { SGA } & \text { Small for gestational age } \\ \text { T1DM } & \text { Type } 1 \text { diabetes mellitus } \\ \text { T2DM } & \text { Type } 2 \text { diabetes mellitus } \\ \text { TL4 } & \text { Toll-like receptor } 4 \\ \text { UtSM } & \text { Myometrial smooth muscle } \\ \text { VDR } & \text { Vitamin D receptor } \\ \text { VSMC } & \text { Smooth muscle cells of the placental vessels }\end{array}$

\section{References}

1. Holick, M.F. Vitamin D: Importance in the prevention of cancers, type 1 diabetes, heart disease, and osteoporosis. Am. J. Clin. Nutr. 2004, 79, 362-371. [PubMed]

2. Barrera, D.; Avila, E.; Hernandez, G.; Mendez, I.; Gonzalez, L.; Halhali, A.; Larrea, F.; Morales, A.; Diaz, L. Calcitriol affects hcg gene transcription in cultured human syncytiotrophoblasts. Reprod. Biol. Endocrinol. 2008, 6, 3. [CrossRef] [PubMed]

3. Masuda, S.; Jones, G. Promise of vitamin D analogues in the treatment of hyperproliferative conditions. Mol. Cancer Ther. 2006, 5, 797-808. [CrossRef] [PubMed] 
4. DeLuca, H.F. Overview of general physiologic features and functions of vitamin d. Am. J. Clin. Nutr. 2004, 80, 1689S-1696S. [PubMed]

5. Kovacs, C.S.; Kronenberg, H.M. Maternal-fetal calcium and bone metabolism during pregnancy, puerperium, and lactation. Endocr. Rev. 1997, 18, 832-872. [CrossRef] [PubMed]

6. El Baba, K.; Zantout, M.S.; Akel, R.; Azar, S.T. Seasonal variation of vitamin D and hba(1c) levels in patients with type 1 diabetes mellitus in the middle east. Int. J. Gen. Med. 2011, 4, 635-638. [PubMed]

7. Baz-Hecht, M.; Goldfine, A.B. The impact of vitamin D deficiency on diabetes and cardiovascular risk. Curr. Opin. Endocrinol. Diabetes Obes. 2010, 17, 113-119. [CrossRef] [PubMed]

8. Zhang, C.; Qiu, C.; Hu, F.B.; David, R.M.; van Dam, R.M.; Bralley, A.; Williams, M.A. Maternal plasma 25-hydroxyvitamin d concentrations and the risk for gestational diabetes mellitus. PLoS ONE 2008, 3, e3753. [CrossRef] [PubMed]

9. Haussler, M.R.; Haussler, C.A.; Bartik, L.; Whitfield, G.K.; Hsieh, J.C.; Slater, S.; Jurutka, P.W. Vitamin D receptor: Molecular signaling and actions of nutritional ligands in disease prevention. Nutr. Rev. 2008, 66, S98-S112. [CrossRef] [PubMed]

10. Palomer, X.; González-Clemente, J.M.; Blanco-Vaca, F.; Mauricio, D. Role of vitamin D in the pathogenesis of type 2 diabetes mellitus. Diabetes Obes. Metab. 2008, 10, 185-197. [CrossRef] [PubMed]

11. Norman, A.W.; Bishop, J.E.; Bula, C.M.; Olivera, C.J.; Mizwicki, M.T.; Zanello, L.P.; Ishida, H.; Okamura, W.H. Molecular tools for study of genomic and rapid signal transduction responses initiated by 1 alpha,25(oh)(2)-vitamin d(3). Steroids 2002, 67, 457-466. [CrossRef]

12. Menegaz, D.; Mizwicki, M.T.; Barrientos-Duran, A.; Chen, N.; Henry, H.L.; Norman, A.W. Vitamin d receptor (vdr) regulation of voltage-gated chloride channels by ligands preferring a vdr-alternative pocket (vdr-ap). Mol. Endocrinol. 2011, 25, 1289-1300. [CrossRef] [PubMed]

13. Shin, J.S.; Choi, M.Y.; Longtine, M.S.; Nelson, D.M. Vitamin d effects on pregnancy and the placenta. Placenta 1027, 31, 1027-1034. [CrossRef] [PubMed]

14. Labuda, M.; Fujiwara, T.M.; Ross, M.V.; Morgan, K.; Garcia-Heras, J.; Ledbetter, D.H.; Hughes, M.R.; Glorieux, F.H. Two hereditary defects related to vitamin D metabolism map to the same region of human chromosome 12q13-14. J. Bone Miner. Res. 1992, 7, 1447-1453. [CrossRef] [PubMed]

15. Uitterlinden, A.G.; Fang, Y.; van Meurs, J.B.J.; van Leeuwen, H.; Pols, H.A.P. Vitamin D receptor gene polymorphisms in relation to vitamin D related disease states. J. Steroid Biochem. Mol. Biol. 2004, 89, 187-193. [CrossRef] [PubMed]

16. Daiger, S.P.; Schanfield, M.S.; Cavalli-Sforza, L.L. Group-specific component (gc) proteins bind vitamin D and 25-hydroxyvitamin d. Proc. Natl. Acad. Sci. USA 1975, 72, 2076-2080. [CrossRef] [PubMed]

17. Wang, T.J.; Zhang, F.; Richards, J.B.; Kestenbaum, B.; van Meurs, J.B.; Berry, D.; Kiel, D.; Streeten, E.A.; Ohlsson, C.; Koller, D.L.; et al. Common genetic determinants of vitamin D insufficiency: A genome-wide association study. Lancet 2010, 376, 180-188. [CrossRef]

18. Uitterlinden, A.G.; Fang, Y.; Van Meurs, J.B.; Pols, H.A.; Van Leeuwen, J.P. Genetics and biology of vitamin D receptor polymorphisms. Gene 2004, 338, 143-156. [CrossRef] [PubMed]

19. Manzon, L.; Altarescu, G.; Tevet, A.; Schimmel, M.S.; Elstein, D.; Samueloff, A.; Grisaru-Granovsky, S. Vitamin $\mathrm{d}$ receptor polymorphism foki is associated with spontaneous idiopathic preterm birth in an israeli population. Eur. J. Obstet. Gynecol. Reprod. Biol. 2014, 177, 84-88. [CrossRef] [PubMed]

20. Jorde, R.; Schirmer, H.; Wilsgaard, T.; Joakimsen, R.M.; Mathiesen, E.B.; Njølstad, I.; Løchen, M.-L.; Figenschau, Y.; Berg, J.P.; Svartberg, J.; et al. Polymorphisms related to the serum 25-hydroxyvitamin $\mathrm{d}$ level and risk of myocardial infarction, diabetes, cancer and mortality. The tromsø study. PLoS ONE 2012, 7, e37295. [CrossRef] [PubMed]

21. Valdivielso, J.M.; Fernandez, E. Vitamin d receptor polymorphisms and diseases. Clin. Chim. Acta 2006, 371, 1-12. [CrossRef] [PubMed]

22. Whitfield, G.K.; Remus, L.S.; Jurutka, P.W.; Zitzer, H.; Oza, A.K.; Dang, H.T.; Haussler, C.A.; Galligan, M.A.; Thatcher, M.L.; Encinas Dominguez, C.; et al. Functionally relevant polymorphisms in the human nuclear vitamin D receptor gene. Mol. Cell. Endocrinol. 2001, 177, 145-159. [CrossRef]

23. Murthi, P.; Yong, H.E.J.; Ngyuen, T.P.H.; Ellery, S.; Singh, H.; Rahman, R.; Dickinson, H.; Walker, D.W.; Davies-Tuck, M.; Wallace, E.M.; et al. Role of the placental vitamin D receptor in modulating feto-placental growth in fetal growth restriction and preeclampsia-affected pregnancies. Front. Physiol. 2016, 7, 43. [CrossRef] [PubMed] 
24. Barrera, D.; Avila, E.; Hernandez, G.; Halhali, A.; Biruete, B.; Larrea, F.; Diaz, L. Estradiol and progesterone synthesis in human placenta is stimulated by calcitriol. J. Steroid Biochem. Mol. Biol. 2007, 103, 529-532. [CrossRef] [PubMed]

25. Evans, K.N.; Bulmer, J.N.; Kilby, M.D.; Hewison, M. Vitamin D and placental-decidual function. J. Soc. Gynecol. Investig. 2004, 11, 263-271. [CrossRef] [PubMed]

26. Halhali, A.; Acker, G.M.; Garabedian, M. 1,25-dihydroxyvitamin d3 induces in vivo the decidualization of rat endometrial cells. J. Reprod. Fertil. 1991, 91, 59-64. [CrossRef] [PubMed]

27. Stephanou, A.; Ross, R.; Handwerger, S. Regulation of human placental lactogen expression by 1,25-dihydroxyvitamin d3. Endocrinology 1994, 135, 2651-2656. [CrossRef] [PubMed]

28. Zehnder, D.; Evans, K.N.; Kilby, M.D.; Bulmer, J.N.; Innes, B.A.; Stewart, P.M.; Hewison, M. The ontogeny of 25-hydroxyvitamin d(3) $1 \alpha$-hydroxylase expression in human placenta and decidua. Am. J. Pathol. 2002, 161, 105-114. [CrossRef]

29. Avila, E.; Diaz, L.; Barrera, D.; Halhali, A.; Mendez, I.; Gonzalez, L.; Zuegel, U.; Steinmeyer, A.; Larrea, F. Regulation of vitamin D hydroxylases gene expression by 1,25-dihydroxyvitamin $\mathrm{d} 3$ and cyclic amp in cultured human syncytiotrophoblasts. J. Steroid Biochem. Mol. Biol. 2007, 103, 90-96. [CrossRef] [PubMed]

30. Liu, N.; Kaplan, A.T.; Low, J.; Nguyen, L.; Liu, G.Y.; Equils, O.; Hewison, M. Vitamin D induces innate antibacterial responses in human trophoblasts via an intracrine pathway. Biol. Reprod. 2009, 80, 398-406. [CrossRef] [PubMed]

31. Shahbazi, M.; Jeddi-Tehrani, M.; Zareie, M.; Salek-Moghaddam, A.; Akhondi, M.M.; Bahmanpoor, M.; Sadeghi, M.R.; Zarnani, A.H. Expression profiling of vitamin D receptor in placenta, decidua and ovary of pregnant mice. Placenta 2011, 32, 657-664. [CrossRef] [PubMed]

32. Pospechova, K.; Rozehnal, V.; Stejskalova, L.; Vrzal, R.; Pospisilova, N.; Jamborova, G.; May, K.; Siegmund, W.; Dvorak, Z.; Nachtigal, P.; et al. Expression and activity of vitamin D receptor in the human placenta and in choriocarcinoma bewo and jeg-3 cell lines. Mol. Cell. Endocrinol. 2009, 299, 178-187. [CrossRef] [PubMed]

33. Evans, K.N.; Nguyen, L.; Chan, J.; Innes, B.A.; Bulmer, J.N.; Kilby, M.D.; Hewison, M. Effects of 25-hydroxyvitamin $\mathrm{d} 3$ and 1,25-dihydroxyvitamin $\mathrm{d} 3$ on cytokine production by human decidual cells. Biol. Reprod. 2006, 75, 816-822. [CrossRef] [PubMed]

34. Liu, N.Q.; Kaplan, A.T.; Lagishetty, V.; Ouyang, Y.B.; Ouyang, Y.; Simmons, C.F.; Equils, O.; Hewison, M. Vitamin $d$ and the regulation of placental inflammation. J. Immunol. 2011, 186, 5968-5974. [CrossRef] [PubMed]

35. Christakos, S.; Dhawan, P.; Verstuyf, A.; Verlinden, L.; Carmeliet, G. Vitamin D: Metabolism, molecular mechanism of action, and pleiotropic effects. Physiol. Rev. 2016, 96, 365-408. [CrossRef] [PubMed]

36. Steegers, E.A.; von Dadelszen, P.; Duvekot, J.J.; Pijnenborg, R. Pre-eclampsia. Lancet 2010, 376, 631-644. [CrossRef]

37. Kaufmann, P.; Black, S.; Huppertz, B. Endovascular trophoblast invasion: Implications for the pathogenesis of intrauterine growth retardation and preeclampsia. Biol. Reprod. 2003, 69, 1-7. [CrossRef] [PubMed]

38. Chen, C.-P.; Bajoria, R.; Aplin, J.D. Decreased vascularization and cell proliferation in placentas of intrauterine growth-restricted fetuses with abnormal umbilical artery flow velocity waveforms. Am. J. Obstet. Gynecol. 2002, 187, 764-769. [CrossRef] [PubMed]

39. Bodnar, L.M.; Catov, J.M.; Simhan, H.N.; Holick, M.F.; Powers, R.W.; Roberts, J.M. Maternal vitamin D deficiency increases the risk of preeclampsia. J. Clin. Endocrinol. Metab. 2007, 92, 3517-3522. [CrossRef] [PubMed]

40. Fischer, D.; Schroer, A.; Ludders, D.; Cordes, T.; Bucker, B.; Reichrath, J.; Friedrich, M. Metabolism of vitamin $\mathrm{d} 3$ in the placental tissue of normal and preeclampsia complicated pregnancies and premature births. Clin. Exp. Obstet. Gynecol. 2007, 34, 80-84. [PubMed]

41. Baker, A.M.; Haeri, S.; Camargo, C.A., Jr.; Espinola, J.A.; Stuebe, A.M. A nested case-control study of midgestation vitamin D deficiency and risk of severe preeclampsia. J. Clin. Endocrinol. Metab. 2010, 95, 5105-5109. [CrossRef] [PubMed]

42. Robinson, C.J.; Alanis, M.C.; Wagner, C.L.; Hollis, B.W.; Johnson, D.D. Plasma 25-hydroxyvitamin d levels in early-onset severe preeclampsia. Am. J. Obstet. Gynecol. 2010, 203. [CrossRef] [PubMed]

43. Bodnar, L.M.; Simhan, H.N.; Catov, J.M.; Roberts, J.M.; Platt, R.W.; Diesel, J.C.; Klebanoff, M.A. Maternal vitamin D status and the risk of mild and severe preeclampsia. Epidemiology 2014, 25, 207-214. [CrossRef] [PubMed] 
44. Tamblyn, J.A.; Susarla, R.; Jenkinson, C.; Jeffery, L.E.; Ohizua, O.; Chun, R.F.; Chan, S.Y.; Kilby, M.D.; Hewison, M. Dysregulation of maternal and placental vitamin D metabolism in preeclampsia. Placenta 2017, 50, 70-77. [CrossRef] [PubMed]

45. August, P.; Marcaccio, B.; Gertner, J.M.; Druzin, M.L.; Resnick, L.M.; Laragh, J.H. Abnormal 1,25-dihydroxyvitamin d metabolism in preeclampsia. Am. J. Obstet. Gynecol. 1992, 166, 1295-1299. [CrossRef]

46. Halhali, A.; Tovar, A.R.; Torres, N.; Bourges, H.; Garabedian, M.; Larrea, F. Preeclampsia is associated with low circulating levels of insulin-like growth factor i and 1,25-dihydroxyvitamin $\mathrm{d}$ in maternal and umbilical cord compartments. J. Clin. Endocrinol. Metab. 2000, 85, 1828-1833. [PubMed]

47. Seely, E.W.; Wood, R.J.; Brown, E.M.; Graves, S.W. Lower serum ionized calcium and abnormal calciotropic hormone levels in preeclampsia. J. Clin. Endocrinol. Metab. 1992, 74, 1436-1440. [PubMed]

48. Hypponen, E. Vitamin d for the prevention of preeclampsia? A hypothesis. Nutr. Rev. 2005, 63, $225-232$. [CrossRef] [PubMed]

49. Chan, S.Y.; Susarla, R.; Canovas, D.; Vasilopoulou, E.; Ohizua, O.; McCabe, C.J.; Hewison, M.; Kilby, M.D. Vitamin D promotes human extravillous trophoblast invasion in vitro. Placenta 2015, 36, 403-409. [CrossRef] [PubMed]

50. Tarcin, O.; Yavuz, D.G.; Ozben, B.; Telli, A.; Ogunc, A.V.; Yuksel, M.; Toprak, A.; Yazici, D.; Sancak, S.; Deyneli, O.; et al. Effect of vitamin D deficiency and replacement on endothelial function in asymptomatic subjects. J. Clin. Endocrinol. Metab. 2009, 94, 4023-4030. [CrossRef] [PubMed]

51. Novakovic, B.; Sibson, M.; Ng, H.K.; Manuelpillai, U.; Rakyan, V.; Down, T.; Beck, S.; Fournier, T.; Evain-Brion, D.; Dimitriadis, E.; et al. Placenta-specific methylation of the vitamin D 24-hydroxylase gene: Implications for feedback autoregulation of active vitamin D levels at the fetomaternal interface. J. Biol. Chem. 2009, 284, 14838-14848. [CrossRef] [PubMed]

52. Saffery, R.; Ellis, J.; Morley, R. A convergent model for placental dysfunction encompassing combined sub-optimal one-carbon donor and vitamin D bioavailability. Med. Hypotheses 2009, 73, 1023-1028. [CrossRef] [PubMed]

53. Ndiaye, N.C.; Said, E.S.; Stathopoulou, M.G.; Siest, G.; Tsai, M.Y.; Visvikis-Siest, S. Epistatic study reveals two genetic interactions in blood pressure regulation. BMC Med. Genet. 2013, 14, 2. [CrossRef] [PubMed]

54. Wang, L.; Ma, J.; Manson, J.E.; Buring, J.E.; Gaziano, J.M.; Sesso, H.D. A prospective study of plasma vitamin D metabolites, vitamin D receptor gene polymorphisms, and risk of hypertension in men. Eur. J. Nutr. 2013, 52, 1771-1779. [CrossRef] [PubMed]

55. Swapna, N.; Vamsi, U.M.; Usha, G.; Padma, T. Risk conferred by foki polymorphism of vitamin D receptor (vdr) gene for essential hypertension. Indian J. Hum. Genet. 2011, 17, 201-206. [PubMed]

56. Li, Y.C. Vitamin d regulation of the renin-angiotensin system. J. Cell. Biochem. 2003, 88, 327-331. [CrossRef] [PubMed]

57. Vaidya, A.; Sun, B.; Forman, J.P.; Hopkins, P.N.; Brown, N.J.; Kolatkar, N.S.; Williams, G.H.; Williams, J.S. The fok1 vitamin D receptor gene polymorphism is associated with plasma renin activity in caucasians. Clin. Endocrinol. 2011, 74, 783-790. [CrossRef] [PubMed]

58. Sandrim, V.C.; Palei, A.C.; Cavalli, R.C.; Araujo, F.M.; Ramos, E.S.; Duarte, G.; Tanus-Santos, J.E. Enos haplotypes associated with gestational hypertension or preeclampsia. Pharmacogenomics 2008, 9, 1467-1473. [CrossRef] [PubMed]

59. Sandrim, V.C.; Palei, A.C.; Luizon, M.R.; Izidoro-Toledo, T.C.; Cavalli, R.C.; Tanus-Santos, J.E. Enos haplotypes affect the responsiveness to antihypertensive therapy in preeclampsia but not in gestational hypertension. Pharmacogenom. J. 2010, 10, 40-45. [CrossRef] [PubMed]

60. Palei, A.C.; Sandrim, V.C.; Duarte, G.; Cavalli, R.C.; Gerlach, R.F.; Tanus-Santos, J.E. Matrix metalloproteinase (mmp)-9 genotypes and haplotypes in preeclampsia and gestational hypertension. Clin. Chim. Acta 2010, 411, 874-877. [CrossRef] [PubMed]

61. Rezende, V.B.; Sandrim, V.C.; Palei, A.C.; Machado, L.; Cavalli, R.C.; Duarte, G.; Tanus-Santos, J.E. Vitamin D receptor polymorphisms in hypertensive disorders of pregnancy. Mol. Biol. Rep. 2012, 39, 10903-10906. [CrossRef] [PubMed]

62. McIntire, D.D.; Bloom, S.L.; Casey, B.M.; Leveno, K.J. Birth weight in relation to morbidity and mortality among newborn infants. N. Engl. J. Med. 1999, 340, 1234-1238. [CrossRef] [PubMed]

63. Mongelli, M.; Gardosi, J. Fetal growth. Curr. Opin. Obstet. Gynecol. 2000, 12, 111-115. [CrossRef] [PubMed] 
64. Scifres, C.M.; Nelson, D.M. Intrauterine growth restriction, human placental development and trophoblast cell death. J. Physiol. 2009, 587, 3453-3458. [CrossRef] [PubMed]

65. Godfrey, K.M.; Barker, D.J. Fetal programming and adult health. Public Health Nutr. 2001, 4, 611-624. [CrossRef] [PubMed]

66. Barker, D.J.; Eriksson, J.G.; Forsen, T.; Osmond, C. Fetal origins of adult disease: Strength of effects and biological basis. Int. J. Epidemiol. 2002, 31, 1235-1239. [CrossRef] [PubMed]

67. Steffensen, F.H.; Sorensen, H.T.; Gillman, M.W.; Rothman, K.J.; Sabroe, S.; Fischer, P.; Olsen, J. Low birth weight and preterm delivery as risk factors for asthma and atopic dermatitis in young adult males. Epidemiology 2000, 11, 185-188. [CrossRef] [PubMed]

68. Frisk, V.; Amsel, R.; Whyte, H.E. The importance of head growth patterns in predicting the cognitive abilities and literacy skills of small-for-gestational-age children. Dev. Neuropsychol. 2002, 22, 565-593. [CrossRef] [PubMed]

69. Rosso, I.M.; Cannon, T.D.; Huttunen, T.; Huttunen, M.O.; Lonnqvist, J.; Gasperoni, T.L. Obstetric risk factors for early-onset schizophrenia in a finnish birth cohort. Am. J. Psychiatry 2000, 157, 801-807. [CrossRef] [PubMed]

70. Gale, C.R.; Martyn, C.N. Birth weight and later risk of depression in a national birth cohort. Br. J. Psychiatry J. Ment. Sci. 2004, 184, 28-33. [CrossRef]

71. Sankaran, S.; Kyle, P.M. Aetiology and pathogenesis of iugr. Best Pract. Res. Clin. Obstet. Gynaecol. 2009, 23, 765-777. [CrossRef] [PubMed]

72. Robinson, J.S.; Moore, V.M.; Owens, J.A.; McMillen, I.C. Origins of fetal growth restriction. Eur J. Obstet. Gynecol. Reprod. Biol. 2000, 92, 13-19. [CrossRef]

73. Wei, S.Q.; Qi, H.P.; Luo, Z.C.; Fraser, W.D. Maternal vitamin D status and adverse pregnancy outcomes: A systematic review and meta-analysis. J. Matern.-Fetal Neonatal Med. 2013, 26, 889-899. [CrossRef] [PubMed]

74. Billaudel, B.; Labriji-Mestaghanmi, H.; Sutter, B.C.; Malaisse, W.J. Vitamin D and pancreatic islet function. II. Dynamics of insulin release and cationic fluxes. J. Endocrinol. Investig. 1988, 11, 585-593. [CrossRef] [PubMed]

75. Galthen-Sorensen, M.; Andersen, L.B.; Sperling, L.; Christesen, H.T. Maternal 25-hydroxyvitamin d level and fetal bone growth assessed by ultrasound: A systematic review. Ultrasound Obstet. Gynecol. 2014, 44, 633-640. [CrossRef] [PubMed]

76. Schneuer, F.J.; Roberts, C.L.; Guilbert, C.; Simpson, J.M.; Algert, C.S.; Khambalia, A.Z.; Tasevski, V.; Ashton, A.W.; Morris, J.M.; Nassar, N. Effects of maternal serum 25-hydroxyvitamin d concentrations in the first trimester on subsequent pregnancy outcomes in an australian population. Am. J. Clin. Nutr. 2014, 99, 287-295. [CrossRef] [PubMed]

77. Eckhardt, C.L.; Gernand, A.D.; Roth, D.E.; Bodnar, L.M. Maternal vitamin D status and infant anthropometry in a us multi-centre cohort study. Ann. Hum. Biol. 2015, 42, 215-222. [CrossRef] [PubMed]

78. Gernand, A.D.; Simhan, H.N.; Klebanoff, M.A.; Bodnar, L.M. Maternal serum 25-hydroxyvitamin d and measures of newborn and placental weight in a U.S. Multicenter cohort study. J. Clin. Endocrinol. Metab. 2013, 98, 398-404. [CrossRef] [PubMed]

79. Eggemoen, A.R.; Jenum, A.K.; Mdala, I.; Knutsen, K.V.; Lagerlov, P.; Sletner, L. Vitamin d levels during pregnancy and associations with birth weight and body composition of the newborn: A longitudinal multiethnic population-based study. Br. J. Nutr. 2017, 117, 985-993. [CrossRef] [PubMed]

80. Crocker, I.P.; Cooper, S.; Ong, S.C.; Baker, P.N. Differences in apoptotic susceptibility of cytotrophoblasts and syncytiotrophoblasts in normal pregnancy to those complicated with preeclampsia and intrauterine growth restriction. Am. J. Pathol. 2003, 162, 637-643. [CrossRef]

81. Newhouse, S.M.; Davidge, S.T.; Winkler-Lowen, B.; Demianczuk, N.; Guilbert, L.J. In vitro differentiation of villous trophoblasts from pregnancies complicated by intrauterine growth restriction with and without pre-eclampsia. Placenta 2007, 28, 999-1003. [CrossRef] [PubMed]

82. Samuel, S.; Sitrin, M.D. Vitamin d's role in cell proliferation and differentiation. Nutr. Rev. 2008, 66, S116-S124. [CrossRef] [PubMed]

83. Nguyen, T.P.; Yong, H.E.; Chollangi, T.; Borg, A.J.; Brennecke, S.P.; Murthi, P. Placental vitamin D receptor expression is decreased in human idiopathic fetal growth restriction. J. Mol. Med. (Berl.) 2015, 93, 795-805. [CrossRef] [PubMed] 
84. Huppertz, B.; Kingdom, J.C. Apoptosis in the trophoblast-role of apoptosis in placental morphogenesis. J. Soc. Gynecol. Investig. 2004, 11, 353-362. [CrossRef] [PubMed]

85. Barrera, G.; Toaldo, C.; Pizzimenti, S.; Cerbone, A.; Pettazzoni, P.; Dianzani, M.U.; Ferretti, C. The role of ppar ligands in controlling growth-related gene expression and their interaction with lipoperoxidation products. PPAR Res. 2008, 2008, 524671. [CrossRef] [PubMed]

86. Tuan, R.S.; Moore, C.J.; Brittingham, J.W.; Kirwin, J.J.; Akins, R.E.; Wong, M. In vitro study of placental trophoblast calcium uptake using JEG-3 human choriocarcinoma cells. J. Cell Sci. 1991, 98 Pt 3, 333-342. [PubMed]

87. Avila, E.; Diaz, L.; Halhali, A.; Larrea, F. Regulation of 25-hydroxyvitamin d3 1alpha-hydroxylase, 1,25-dihydroxyvitamin d3 24-hydroxylase and vitamin D receptor gene expression by 8-bromo cyclic AMP in cultured human syncytiotrophoblast cells. J. Steroid Biochem. Mol. Biol. 2004, 89-90, 115-119. [CrossRef] [PubMed]

88. Sandovici, I.; Hoelle, K.; Angiolini, E.; Constancia, M. Placental adaptations to the maternal-fetal environment: Implications for fetal growth and developmental programming. Reprod. Biomed. Online 2012, 25, 68-89. [CrossRef] [PubMed]

89. Jurutka, P.W.; Whitfield, G.K.; Hsieh, J.C.; Thompson, P.D.; Haussler, C.A.; Haussler, M.R. Molecular nature of the vitamin D receptor and its role in regulation of gene expression. Rev. Endocr. Metab. Disord. 2001, 2, 203-216. [CrossRef] [PubMed]

90. Morley, J.E. Vitamin D redux. J. Am. Med. Dir. Assoc. 2009, 10, 591-592. [CrossRef] [PubMed]

91. Swamy, G.K.; Garrett, M.E.; Miranda, M.L.; Ashley-Koch, A.E. Maternal vitamin D receptor genetic variation contributes to infant birthweight among black mothers. Am. J. Med. Genet. Part A 2011, 155, 1264-1271. [CrossRef] [PubMed]

92. Metzger, B.E.; Coustan, D.R. Summary and recommendations of the fourth international workshop-conference on gestational diabetes mellitus. The organizing committee. Diabetes Care 1998, 21 (Suppl. 2), B161-B167. [PubMed]

93. Knabl, J.; Huttenbrenner, R.; Hutter, S.; Gunthner-Biller, M.; Riedel, C.; Hiden, U.; Kainer, F.; Desoye, G.; Jeschke, U. Gestational diabetes mellitus upregulates vitamin D receptor in extravillous trophoblasts and fetoplacental endothelial cells. Reprod. Sci. 2015, 22, 358-366. [CrossRef] [PubMed]

94. Butte, N.F. Carbohydrate and lipid metabolism in pregnancy: Normal compared with gestational diabetes mellitus. Am. J. Clin. Nutr. 2000, 71, 1256s-1261s. [PubMed]

95. Hartling, L.; Dryden, D.M.; Guthrie, A.; Muise, M.; Vandermeer, B.; Aktary, W.M.; Pasichnyk, D.; Seida, J.C.; Donovan, L. Screening and diagnosing gestational diabetes mellitus. Evid. Rep./Technol. Assess. 2012, $210,1-327$.

96. Nar, G.; Inci, S.; Aksan, G.; Unal, O.K.; Nar, R.; Soylu, K. The relationship between epicardial fat thickness and gestational diabetes mellitus. Diabetol. Metab. Syndr. 2014, 6, 120. [CrossRef] [PubMed]

97. Bellamy, L.; Casas, J.P.; Hingorani, A.D.; Williams, D. Type 2 diabetes mellitus after gestational diabetes: A systematic review and meta-analysis. Lancet 2009, 373, 1773-1779. [CrossRef]

98. Soheilykhah, S.; Mojibian, M.; Rashidi, M.; Rahimi-Saghand, S.; Jafari, F. Maternal vitamin D status in gestational diabetes mellitus. Nutr. Clin. Pract. 2010, 25, 524-527. [CrossRef] [PubMed]

99. Maghbooli, Z.; Hossein-Nezhad, A.; Karimi, F.; Shafaei, A.R.; Larijani, B. Correlation between vitamin d3 deficiency and insulin resistance in pregnancy. Diabetes Metab. Res. Rev. 2008, 24, 27-32. [CrossRef] [PubMed]

100. Clifton-Bligh, R.J.; McElduff, P.; McElduff, A. Maternal vitamin D deficiency, ethnicity and gestational diabetes. Diabet. Med. 2008, 25, 678-684. [CrossRef] [PubMed]

101. Baker, A.M.; Haeri, S.; Camargo, C.A., Jr.; Stuebe, A.M.; Boggess, K.A. First-trimester maternal vitamin D status and risk for gestational diabetes ( $\mathrm{gdm})$ a nested case-control study. Diabetes Metab. Res. Rev. 2012, 28, 164-168. [CrossRef] [PubMed]

102. Makgoba, M.; Nelson, S.M.; Savvidou, M.; Messow, C.M.; Nicolaides, K.; Sattar, N. First-trimester circulating 25-hydroxyvitamin d levels and development of gestational diabetes mellitus. Diabetes Care 2011, 34, 1091-1093. [CrossRef] [PubMed]

103. Farrant, H.J.; Krishnaveni, G.V.; Hill, J.C.; Boucher, B.J.; Fisher, D.J.; Noonan, K.; Osmond, C.; Veena, S.R.; Fall, C.H. Vitamin D insufficiency is common in indian mothers but is not associated with gestational diabetes or variation in newborn size. Eur. J. Clin. Nutr. 2009, 63, 646-652. [CrossRef] [PubMed] 
104. Burris, H.H.; Rifas-Shiman, S.L.; Kleinman, K.; Litonjua, A.A.; Huh, S.Y.; Rich-Edwards, J.W.; Camargo, C.A., Jr.; Gillman, M.W. Vitamin D deficiency in pregnancy and gestational diabetes mellitus. Am. J. Obstet. Gynecol. 2012, 207. [CrossRef] [PubMed]

105. Aghajafari, F.; Nagulesapillai, T.; Ronksley, P.E.; Tough, S.C.; O'Beirne, M.; Rabi, D.M. Association between maternal serum 25-hydroxyvitamin d level and pregnancy and neonatal outcomes: Systematic review and meta-analysis of observational studies. BMJ 2013, 346, f1169. [CrossRef] [PubMed]

106. Triunfo, S.; Lanzone, A.; Lindqvist, P.G. Low maternal circulating levels of vitamin $D$ as potential determinant in the development of gestational diabetes mellitus. J. Endocrinol. Investig. 2017, 40, 1049-1059. [CrossRef] [PubMed]

107. Darwish, H.; DeLuca, H.F. Vitamin D-regulated gene expression. Crit. Rev. Eukaryot. Gene Expr. 1993, 3, 89-116. [PubMed]

108. Potera, C. Diet and nutrition: Vitamin D regulates ms gene. Environ. Health Perspect. 2009, 117, A196. [CrossRef] [PubMed]

109. Senti, J.; Thiele, D.K.; Anderson, C.M. Maternal vitamin D status as a critical determinant in gestational diabetes. J. Obstet. Gynecol. Neonatal Nurs. JOGNN 2012, 41, 328-338. [CrossRef] [PubMed]

110. Holick, M.F. Vitamin D deficiency. N. Engl. J. Med. 2007, 357, 266-281. [CrossRef] [PubMed]

111. Bourlon, P.M.; Billaudel, B.; Faure-Dussert, A. Influence of vitamin d 3 deficiency and 1,25 dihydroxyvitamin $\mathrm{d} 3$ on de novo insulin biosynthesis in the islets of the rat endocrine pancreas. J. Endocrinol. 1999, 160, 87-95. [CrossRef] [PubMed]

112. Cade, C.; Norman, A.W. Vitamin d3 improves impaired glucose tolerance and insulin secretion in the vitamin d-deficient rat in vivo. Endocrinology 1986, 119, 84-90. [CrossRef] [PubMed]

113. Roth, J.; Bonner-Weir, S.; Norman, A.W.; Orci, L. Immunocytochemistry of vitamin d-dependent calcium binding protein in chick pancreas: Exclusive localization. Endocrinology 1982, 110, 2216-2218. [CrossRef] [PubMed]

114. Kadowaki, S.; Norman, A.W. Dietary vitamin D is essential for normal insulin secretion from the perfused rat pancreas. J. Clin. Investig. 1984, 73, 759-766. [CrossRef] [PubMed]

115. Norman, A.W.; Frankel, J.B.; Heldt, A.M.; Grodsky, G.M. Vitamin D deficiency inhibits pancreatic secretion of insulin. Science 1980, 209, 823-825. [CrossRef] [PubMed]

116. Chiu, K.C.; Chu, A.; Go, V.L.; Saad, M.F. Hypovitaminosis d is associated with insulin resistance and beta cell dysfunction. Am. J. Clin. Nutr. 2004, 79, 820-825. [PubMed]

117. Scragg, R.; Holdaway, I.; Singh, V.; Metcalf, P.; Baker, J.; Dryson, E. Serum 25-hydroxyvitamin d3 levels decreased in impaired glucose tolerance and diabetes mellitus. Diabetes Res. Clin. Pract. 1995, 27, 181-188. [CrossRef]

118. Ojuka, E.O. Role of calcium and amp kinase in the regulation of mitochondrial biogenesis and glut4 levels in muscle. Proc. Nutr. Soc. 2004, 63, 275-278. [CrossRef] [PubMed]

119. Wright, D.C.; Hucker, K.A.; Holloszy, J.O.; Han, D.H. Ca2+ and ampk both mediate stimulation of glucose transport by muscle contractions. Diabetes 2004, 53, 330-335. [CrossRef] [PubMed]

120. Williams, P.F.; Caterson, I.D.; Cooney, G.J.; Zilkens, R.R.; Turtle, J.R. High affinity insulin binding and insulin receptor-effector coupling: Modulation by $\mathrm{Ca}^{2+}$. Cell Calcium 1990, 11, 547-556. [CrossRef]

121. Draznin, B.; Sussman, K.; Kao, M.; Lewis, D.; Sherman, N. The existence of an optimal range of cytosolic free calcium for insulin-stimulated glucose transport in rat adipocytes. J. Biol. Chem. 1987, 262, 14385-14388. [PubMed]

122. Plehwe, W.E.; Williams, P.F.; Caterson, I.D.; Harrison, L.C.; Turtle, J.R. Calcium-dependence of insulin receptor phosphorylation. Biochem. J. 1983, 214, 361-366. [CrossRef] [PubMed]

123. Zemel, M.B. Nutritional and endocrine modulation of intracellular calcium: Implications in obesity, insulin resistance and hypertension. Mol. Cell. Biochem. 1998, 188, 129-136. [CrossRef] [PubMed]

124. Reusch, J.E.; Begum, N.; Sussman, K.E.; Draznin, B. Regulation of glut-4 phosphorylation by intracellular calcium in adipocytes. Endocrinology 1991, 129, 3269-3273. [CrossRef] [PubMed]

125. Maestro, B.; Davila, N.; Carranza, M.C.; Calle, C. Identification of a vitamin D response element in the human insulin receptor gene promoter. J. Steroid Biochem. Mol. Biol. 2003, 84, 223-230. [CrossRef]

126. Maestro, B.; Molero, S.; Bajo, S.; Davila, N.; Calle, C. Transcriptional activation of the human insulin receptor gene by 1,25-dihydroxyvitamin d(3). Cell Biochem. Funct. 2002, 20, 227-232. [CrossRef] [PubMed]

127. Bikle, D. Nonclassic actions of vitamin D. J. Clin. Endocrinol. Metab. 2009, 94, 26-34. [CrossRef] [PubMed] 
128. Riachy, R.; Vandewalle, B.; Kerr Conte, J.; Moerman, E.; Sacchetti, P.; Lukowiak, B.; Gmyr, V.; Bouckenooghe, T.; Dubois, M.; Pattou, F. 1,25-dihydroxyvitamin d3 protects rinm5f and human islet cells against cytokine-induced apoptosis: Implication of the antiapoptotic protein a20. Endocrinology 2002, 143, 4809-4819. [CrossRef] [PubMed]

129. Gysemans, C.A.; Cardozo, A.K.; Callewaert, H.; Giulietti, A.; Hulshagen, L.; Bouillon, R.; Eizirik, D.L.; Mathieu, C. 1,25-dihydroxyvitamin d3 modulates expression of chemokines and cytokines in pancreatic islets: Implications for prevention of diabetes in nonobese diabetic mice. Endocrinology 2005, 146, 1956-1964. [CrossRef] [PubMed]

130. van Etten, E.; Mathieu, C. Immunoregulation by 1,25-dihydroxyvitamin d3: Basic concepts. J. Steroid Biochem. Mol. Biol. 2005, 97, 93-101. [CrossRef] [PubMed]

131. D'Ambrosio, D.; Cippitelli, M.; Cocciolo, M.G.; Mazzeo, D.; Di Lucia, P.; Lang, R.; Sinigaglia, F.; Panina-Bordignon, P. Inhibition of il-12 production by 1,25-dihydroxyvitamin d3. Involvement of nf-kappab downregulation in transcriptional repression of the p40 gene. J. Clin. Investig. 1998, 101, 252-262. [CrossRef] [PubMed]

132. Pittas, A.G.; Joseph, N.A.; Greenberg, A.S. Adipocytokines and insulin resistance. J. Clin Endocrinol. Metab. 2004, 89, 447-452. [CrossRef] [PubMed]

133. Rabinovitch, A.; Suarez-Pinzon, W.L.; Sooy, K.; Strynadka, K.; Christakos, S. Expression of calbindin-d(28k) in a pancreatic islet beta-cell line protects against cytokine-induced apoptosis and necrosis. Endocrinology 2001, 142, 3649-3655. [CrossRef] [PubMed]

134. Kadowaki, S.; Norman, A.W. Pancreatic vitamin D-dependent calcium binding protein: Biochemical properties and response to vitamin D. Arch. Biochem. Biophys. 1984, 233, 228-236. [CrossRef]

135. Radaelli, T.; Varastehpour, A.; Catalano, P.; Hauguel-de Mouzon, S. Gestational diabetes induces placental genes for chronic stress and inflammatory pathways. Diabetes 2003, 52, 2951-2958. [CrossRef] [PubMed]

136. Shoelson, S.E.; Herrero, L.; Naaz, A. Obesity, inflammation, and insulin resistance. Gastroenterology 2007, 132, 2169-2180. [CrossRef] [PubMed]

137. Dong, J.; Wong, S.L.; Lau, C.W.; Lee, H.K.; Ng, C.F.; Zhang, L.; Yao, X.; Chen, Z.Y.; Vanhoutte, P.M.; Huang, Y. Calcitriol protects renovascular function in hypertension by down-regulating angiotensin ii type 1 receptors and reducing oxidative stress. Eur. Heart J. 2012, 33, 2980-2990. [CrossRef] [PubMed]

138. Kumpel, B.M.; Manoussaka, M.S. Placental immunology and maternal alloimmune responses. Vox Sang. 2012, 102, 2-12. [CrossRef] [PubMed]

139. Liu, N.Q.; Hewison, M. Vitamin D, the placenta and pregnancy. Arch. Biochem. Biophys. 2012, 523, 37-47. [CrossRef] [PubMed]

140. Cho, G.J.; Hong, S.C.; Oh, M.J.; Kim, H.J. Vitamin D deficiency in gestational diabetes mellitus and the role of the placenta. Am. J. Obstet. Gynecol. 2013. [CrossRef] [PubMed]

141. Ben-Haroush, A.; Yogev, Y.; Hod, M. Epidemiology of gestational diabetes mellitus and its association with type 2 diabetes. Diabet. Med. 2004, 21, 103-113. [CrossRef] [PubMed]

142. Kim, C.; Berger, D.K.; Chamany, S. Recurrence of gestational diabetes mellitus: A systematic review. Diabetes Care 2007, 30, 1314-1319. [CrossRef] [PubMed]

143. Zhang, C.; Bao, W.; Rong, Y.; Yang, H.; Bowers, K.; Yeung, E.; Kiely, M. Genetic variants and the risk of gestational diabetes mellitus: A systematic review. Hum. Reprod. Update 2013, 19, 376-390. [CrossRef] [PubMed]

144. Aslani, S.; Hossein-Nezhad, A.; Mirzaei, K.; Maghbooli, Z.; Afshar, A.N.; Karimi, F. Vdr foki polymorphism and its potential role in the pathogenesis of gestational diabetes mellitus and its complications. Gynecol. Endocrinol. 2011, 27, 1055-1060. [CrossRef] [PubMed]

145. Rahmannezhad, G.; Mashayekhi, F.J.; Goodarzi, M.T.; Rezvanfar, M.R.; Sadeghi, A. Association between vitamin D receptor apai and taqi gene polymorphisms and gestational diabetes mellitus in an iranian pregnant women population. Gene 2016, 581, 43-47. [CrossRef] [PubMed]

146. Motohashi, Y.; Yamada, S.; Yanagawa, T.; Maruyama, T.; Suzuki, R.; Niino, M.; Fukazawa, T.; Kasuga, A.; Hirose, H.; Matsubara, K.; et al. Vitamin D receptor gene polymorphism affects onset pattern of type 1 diabetes. J. Clin. Endocrinol. Metab. 2003, 88, 3137-3140. [CrossRef] [PubMed]

147. Tizaoui, K.; Kaabachi, W.; Hamzaoui, A.; Hamzaoui, K. Contribution of vdr polymorphisms to type 1 diabetes susceptibility: Systematic review of case-control studies and meta-analysis. J. Steroid Biochem. Mol. Biol. 2014, 143, 240-249. [CrossRef] [PubMed] 
148. Oh, J.Y.; Barrett-Connor, E. Association between vitamin D receptor polymorphism and type 2 diabetes or metabolic syndrome in community-dwelling older adults: The rancho bernardo study. Metabolism 2002, 51, 356-359. [CrossRef] [PubMed]

149. Huerta-Chagoya, A.; Vazquez-Cardenas, P.; Moreno-Macias, H.; Tapia-Maruri, L.; Rodriguez-Guillen, R.; Lopez-Vite, E.; Garcia-Escalante, G.; Escobedo-Aguirre, F.; Parra-Covarrubias, A.; Cordero-Brieno, R.; et al. Genetic determinants for gestational diabetes mellitus and related metabolic traits in mexican women. PLoS ONE 2015, 10, e0126408. [CrossRef] [PubMed]

150. Mao, H.; Li, Q.; Gao, S. Meta-analysis of the relationship between common type 2 diabetes risk gene variants with gestational diabetes mellitus. PLoS ONE 2012, 7, e45882. [CrossRef] [PubMed]

151. Bid, H.K.; Konwar, R.; Aggarwal, C.G.; Gautam, S.; Saxena, M.; Nayak, V.L.; Banerjee, M. Vitamin D receptor (foki, bsmi and taqi) gene polymorphisms and type 2 diabetes mellitus: A north indian study. Indian J. Med. Sci. 2009, 63, 187-194. [PubMed]

152. Sahin, O.A.; Goksen, D.; Ozpinar, A.; Serdar, M.; Onay, H. Association of vitamin D receptor polymorphisms and type 1 diabetes susceptibility in children: A meta-analysis. Endocr. Connect. 2017, 6, 159-171. [CrossRef] [PubMed]

153. Yu, F.; Cui, L.L.; Li, X.; Wang, C.J.; Ba, Y.; Wang, L.; Li, J.; Li, C.; Dai, L.P.; Li, W.J. The genetic polymorphisms in vitamin D receptor and the risk of type 2 diabetes mellitus: An updated meta-analysis. Asia Pac. J. Clin. Nutr. 2016, 25, 614-624. [PubMed]

154. El-Beshbishy, H.A.; Tawfeek, M.A.; Taha, I.M.; FadulElahi, T.; Shaheen, A.Y.; Bardi, F.A.; Sultan, I.I. Association of vitamin $\mathrm{D}$ receptor gene bsmi $(\mathrm{a}>\mathrm{g})$ and foki $(\mathrm{c}>\mathrm{t})$ polymorphism in gestational diabetes among saudi women. Pak. J. Med. Sci. 2015, 31, 1328-1333. [CrossRef] [PubMed]

155. Shi, A.; Wen, J.; Liu, G.; Liu, H.; Fu, Z.; Zhou, J.; Zhu, Y.; Liu, Y.; Guo, X.; Xu, J. Genetic variants in vitamin D signaling pathways and risk of gestational diabetes mellitus. Oncotarget 2016, 7, 67788-67795. [CrossRef] [PubMed]

156. Goldenberg, R.L.; Hauth, J.C.; Andrews, W.W. Intrauterine infection and preterm delivery. N. Engl. J. Med. 2000, 342, 1500-1507. [CrossRef] [PubMed]

157. Romero, R.; Espinoza, J.; Kusanovic, J.P.; Gotsch, F.; Hassan, S.; Erez, O.; Chaiworapongsa, T.; Mazor, M. The preterm parturition syndrome. BJOG 2006, 113 (Suppl. 3), 17-42. [CrossRef] [PubMed]

158. Romero, R.; Espinoza, J.; Goncalves, L.F.; Kusanovic, J.P.; Friel, L.A.; Nien, J.K. Inflammation in preterm and term labour and delivery. Semin. Fetal Neonatal Med. 2006, 11, 317-326. [CrossRef] [PubMed]

159. Martineau, A.R.; Wilkinson, R.J.; Wilkinson, K.A.; Newton, S.M.; Kampmann, B.; Hall, B.M.; Packe, G.E.; Davidson, R.N.; Eldridge, S.M.; Maunsell, Z.J.; et al. A single dose of vitamin D enhances immunity to mycobacteria. Am. J. Respir. Crit. Care Med. 2007, 176, 208-213. [CrossRef] [PubMed]

160. Wagner, C.L.; McNeil, R.B.; Johnson, D.D.; Hulsey, T.C.; Ebeling, M.; Robinson, C.; Hamilton, S.A.; Hollis, B.W. Health characteristics and outcomes of two randomized vitamin D supplementation trials during pregnancy: A combined analysis. J. Steroid Biochem. Mol. Biol. 2013, 136, 313-320. [CrossRef] [PubMed]

161. Thorp, J.M.; Camargo, C.A.; McGee, P.L.; Harper, M.; Klebanoff, M.A.; Sorokin, Y.; Varner, M.W.; Wapner, R.J.; Caritis, S.N.; Iams, J.D.; et al. Vitamin D status and recurrent preterm birth: A nested case-control study in high-risk women. BJOG 2012, 119, 1617-1623. [CrossRef] [PubMed]

162. Bodnar, L.M.; Klebanoff, M.A.; Gernand, A.D.; Platt, R.W.; Parks, W.T.; Catov, J.M.; Simhan, H.N. Maternal vitamin D status and spontaneous preterm birth by placental histology in the us collaborative perinatal project. Am. J. Epidemiol. 2014, 179, 168-176. [CrossRef] [PubMed]

163. Bodnar, L.M.; Rouse, D.J.; Momirova, V.; Peaceman, A.M.; Sciscione, A.; Spong, C.Y.; Varner, M.W.; Malone, F.D.; Iams, J.D.; Mercer, B.M.; et al. Maternal 25-hydroxyvitamin d and preterm birth in twin gestations. Obstet. Gynecol. 2013, 122, 91-98. [CrossRef] [PubMed]

164. Wetta, L.A.; Biggio, J.R.; Cliver, S.; Abramovici, A.; Barnes, S.; Tita, A.T. Is midtrimester vitamin D status associated with spontaneous preterm birth and preeclampsia? Am. J. Perinatol. 2014, 31, 541-546. [PubMed]

165. Amegah, A.K.; Klevor, M.K.; Wagner, C.L. Maternal vitamin D insufficiency and risk of adverse pregnancy and birth outcomes: A systematic review and meta-analysis of longitudinal studies. PLOS ONE 2017, 12, e0173605. [CrossRef] [PubMed]

166. Bodnar, L.M.; Krohn, M.A.; Simhan, H.N. Maternal vitamin D deficiency is associated with bacterial vaginosis in the first trimester of pregnancy. J. Nutr. 2009, 139, 1157-1161. [CrossRef] [PubMed]

167. Hewison, M. Antibacterial effects of vitamin D. Nat. Rev. Endocrinol. 2011, 7, 337-345. [CrossRef] [PubMed] 
168. Sehringer, B.; Schafer, W.R.; Wetzka, B.; Deppert, W.R.; Brunner-Spahr, R.; Benedek, E.; Zahradnik, H.P. Formation of proinflammatory cytokines in human term myometrium is stimulated by lipopolysaccharide but not by corticotropin-releasing hormone. J. Clin. Endocrinol. Metab. 2000, 85, 4859-4865. [CrossRef] [PubMed]

169. Helmer, H.; Tretzmuller, U.; Brunbauer, M.; Kaider, A.; Husslein, P.; Knofler, M. Production of oxytocin receptor and cytokines in primary uterine smooth muscle cells cultivated under inflammatory conditions. J. Soc. Gynecol. Investig. 2002, 9, 15-21. [CrossRef] [PubMed]

170. Romero, R.; Mazor, M.; Tartakovsky, B. Systemic administration of interleukin-1 induces preterm parturition in mice. Am. J. Obstet. Gynecol. 1991, 165, 969-971. [CrossRef]

171. Buhimschi, I.A.; Buhimschi, C.S.; Weiner, C.P. Protective effect of n-acetylcysteine against fetal death and preterm labor induced by maternal inflammation. Am. J. Obstet. Gynecol. 2003, 188, 203-208. [CrossRef] [PubMed]

172. Thota, C.; Farmer, T.; Garfield, R.E.; Menon, R.; Al-Hendy, A. Vitamin D elicits anti-inflammatory response, inhibits contractile-associated proteins, and modulates toll-like receptors in human myometrial cells. Reprod. Sci. 2013, 20, 463-475. [CrossRef] [PubMed]

173. Rosenfeld, T.; Salem, H.; Altarescu, G.; Grisaru-Granovsky, S.; Tevet, A.; Birk, R. Maternal-fetal vitamin D receptor polymorphisms significantly associated with preterm birth. Arch. Gynecol. Obstet. 2017, 296, $215-222$. [CrossRef] [PubMed]

174. Baczynska-Strzecha, M.; Kalinka, J. Influence of apa1 (rs7975232), taq1 (rs731236) and bsm1 (rs154410) polymorphisms of vitamin D receptor on preterm birth risk in the polish population. Ginekol. Pol. 2016, 87, 763-768. [CrossRef] [PubMed]

175. Kovacs, C.S.; Woodland, M.L.; Fudge, N.J.; Friel, J.K. The vitamin d receptor is not required for fetal mineral homeostasis or for the regulation of placental calcium transfer in mice. Am. J. Physiol. Endocrinol. Metab. 2005, 289, E133-E144. [CrossRef] [PubMed]

176. Wilson, R.L.; Buckberry, S.; Spronk, F.; Laurence, J.A.; Leemaqz, S.; O'Leary, S.; Bianco-Miotto, T.; Du, J.; Anderson, P.H.; Roberts, C.T. Vitamin D receptor gene ablation in the conceptus has limited effects on placental morphology, function and pregnancy outcome. PLoS ONE 2015, 10, e0131287. [CrossRef] [PubMed]

177. Liu, N.Q.; Ouyang, Y.; Bulut, Y.; Lagishetty, V.; Chan, S.Y.; Hollis, B.W.; Wagner, C.; Equils, O.; Hewison, M. Dietary vitamin D restriction in pregnant female mice is associated with maternal hypertension and altered placental and fetal development. Endocrinology 2013, 154, 2270-2280. [CrossRef] [PubMed]

178. Burton, G.J.; Jauniaux, E. Placental oxidative stress: From miscarriage to preeclampsia. J. Soc. Gynecol. Investig. 2004, 11, 342-352. [CrossRef] [PubMed]

(C) 2017 by the authors. Licensee MDPI, Basel, Switzerland. This article is an open access article distributed under the terms and conditions of the Creative Commons Attribution (CC BY) license (http:/ / creativecommons.org/licenses/by/4.0/). 